\title{
PREVALENSI VIRUS HEPATITIS PADA PASIEN PENYAKIT GINJAL KRONIK YANG MENJALANI HEMODIALISIS RUTIN BAGIAN ILMU PENYAKIT DALAM RSUP PROF. DR. R. D. KANDOU MANADO
}

\author{
${ }^{1}$ Alvisco Y. Belung \\ ${ }^{2}$ E. Moeis \\ ${ }^{2}$ Frans Wantania \\ ${ }^{1}$ Kandidat Skripsi Fakultas Kedokteran Universitas Sam Ratulangi Manado \\ ${ }^{2}$ Bagian Ilmu Penyakit Dalam, Fakultas Kedokteran Universitas Sam Ratulangi \\ Manado \\ email: alviscoyohanesbelung@gmail.com
}

\begin{abstract}
Chronic Kidney Disease ( CKD ) is a pathophysiological process with diverse etiology resulting in a progressive decline in kidney function. Dialysis is a process of diffusion of solutes and water passively through a porous membrane of a liquid compartment towards other liquid compartments. Hepatitis is a systemic viral infection that attacks the liver. Transmission of Hepatitis B Virus and Hepatitis C Virus is a crucial problem in patients undergoing hemodialysis. This research was conducted by using a retrospective descriptive method. The samples were all positive CKD patients with hepatitis virus in the Hemodialysis Installation of Prof. Dr. R. D. Kandou Manado Hospital. Based on research conducted found that there were 87 patients undergoing hemodialysis with a diagnosis of Chronic Kidney Disease, a total of 25 patients were found positive for Hepatitis $\mathrm{C}$ virus and 14 patients with positive HbsAg.
\end{abstract}

Keywords: Chronic Kidney Disease, Hepatitis Virus, Hemodialysis

\begin{abstract}
Abstrak: Penyakit Ginjal Kronik (PGK) adalah suatu proses patofisiologis dengan etiologi yang beragam, mengakibatkan penurunan fungsi ginjal yang progresif. Dialisis adalah suatu proses difusi zat terlarut dan air secara pasif melalui suatu membran berpori dari satu kompartemen cair menuju kompartemen cair lainnya. Virus Hepatitis merupakan infeksi sistemik yang menyerang hati. Transmisi Virus Hepatitis B dan Virus Hepatitis C merupakan masalah sangat penting pada pasien yang menjalani hemodialisa. Penelitian ini dilakukan dengan menggunakan metode deskriptif retrospektif. Sampel penelitian adalah semua pasien PGK yang positif virus hepatitis di Instalasi Tindakan Hemodialisis RSUP Prof. Dr. R. D. Kandou Manado. Berdasarkan penelitian yang dilakukan didapatkan ada 87 pasien yang menjalani hemodialisis dengan diagnosis Penyakit Ginjal Kronik, sebanyak 25 pasien ditemukan positif Virus Hepatitis C dan 14 pasien dengan HbsAg positif.
\end{abstract}

Kata Kunci: Penyakit Ginjal Kronik, Virus Hepatitis, Hemodialisis 


\section{PENDAHULUAN}

Penyakit Ginjal Kronik (PGK) adalah suatu proses patofisiologis dengan etiologi yang beragam, mengakibatkan penurunan fungsi ginjal yang progresif. Fungsi ginjal dibagi menjadi fungsi ekskresi dan fungsi endrokin dimana pada PGK kedua fungsi ini memburuk walaupun tidak selalu proposional. Fungsi ginjal yang masih tersisa pada stadium akhir PGK sudah minimal sehingga usaha-usaha pengobatan konservatif berupa diet, pembatasan minum, obat-obatan dan lain-lain tidak memberi pertolongan yang diharapkan lagi. Pada stadium ini terdapat akumulasi toksin uremia yang dapat membahayakan kelangsungan hidup pasien. ${ }^{1,2}$

Dialisis adalah suatu proses difusi zat terlarut dan air secara pasif melalui suatu membran berpori dari satu kompartemen cair menuju kompartemen cair lainnya. Hemodialisis merupakan salah satu teknik utama yang digunakan dalam dialisis, prinsip dasar teknik ini yaitu disfusi zat terlarut dan air dari plasma ke larutan dialisis sebagai respon terhadap perbedaan konsentrasi atau tekanan tertentu. $^{3}$

Virus Hepatitis merupakan infeksi sistemik yang menyerang hati. Virus hepatitis termasuk virus hepatotropik yang dapat mengakibatkan virus hepatitis A (HAV), virus hepatitis B (HBV), virus hepatitis C (HCV), delta hepatitis (HDV), dan virus hepatitis E (HEV). Terdapat beberapa agen virus hepatitis lainnya yang baru ditemukan dan diberi nama virus hepatitis F (HFV), hepatitis G (HGV), TT (TTV) dan SEN (SENV), tetapi masih sedikit kasus yang ditemukan. ${ }^{4-6}$

Transmisi blood borne disease seperti virus hepatitis B dan virus hepatitis C merupakan masalah sangat penting pada pasien yang menjalani hemodialisa. 
Untuk itu penulis ingin mengetahui gambaran Virus hepatitis pada pasien Penyakit Ginjal Kronik yang menjalani hemodialisis rutin di SMF Ilmu Penyakit Dalam RSUP Prof. Dr. R. D. Kandou Manado.

\section{METODE PENELITIAN}

Penelitian ini dilakukan pada bulan Desember 2015 - Januari 2016 di bagian Instalasi Tindakan Hemodialisis RSUP Prof. Dr. R. D. Kandou Manado. Penelitian ini bersifat deskriptif retrospektif. Sampel yang diambil adalah semua pasien PGK yang positif virus hepatitis.

\section{HASIL PENELITIAN}

Terdapat 87 pasien yang menjalani hemodialisa dengan diagnosis Penyakit Ginjal Kronik. Pasien dengan Virus Hepatitis C positif didapatkan sebanyak 25 pasien (28,73\%) dan pasien dengan Virus Hepatitis B positif sebanyak 14 pasien $(16,09 \%)$ (lihat Gambar 1).

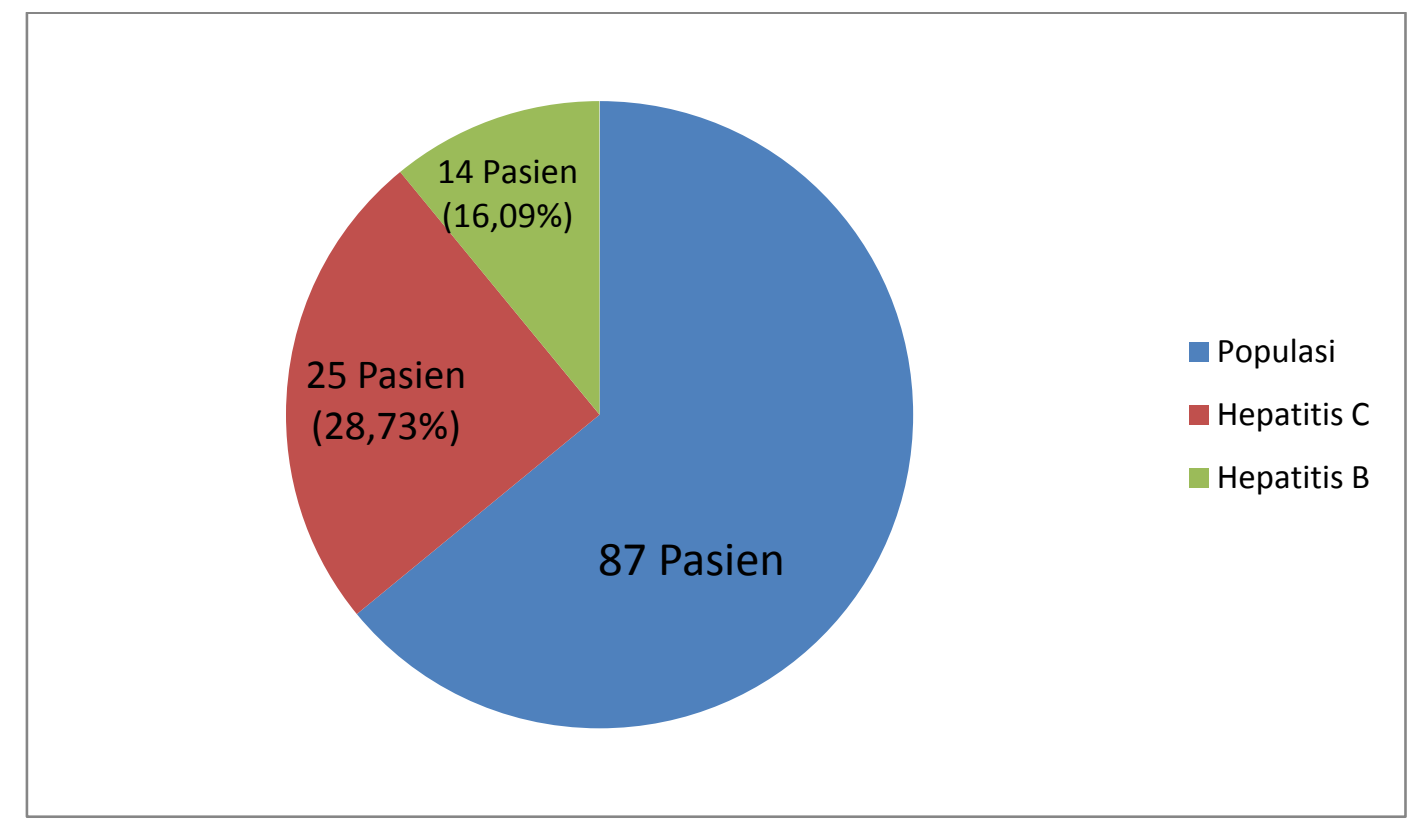

Gambar 1. Populasi dan Sampel 
Berdasarkan kelompok usia, pasien Penyakit Ginjal Kronik yang menjalani hemodialisa dengan Virus hepatitis C memiliki distribusi antara usia 18-29 tahun terdapat 1 orang (4\%), antara usia 30-39 tahun terdapat 2 orang (8\%), antara usia 40-49 tahun terdapat 8 orang (32\%), antara usia 50-59 tahun terdapat 8 orang (32\%), dan antara usia 60-69 tahun terdapat 6 orang (24\%) (lihat Tabel 1).

Tabel 1. Distribusi Sampel Berdasarkan Usia

\begin{tabular}{lcc}
\hline Usia (Tahun) & Jumlah (Orang) & Persentase (\%) \\
\hline $18-29$ & 1 & 4 \\
$30-39$ & 2 & 8 \\
$40-49$ & 8 & 32 \\
$50-59$ & 8 & 32 \\
$60-69$ & 6 & 24 \\
\hline Total & $\mathbf{2 5}$ & $\mathbf{1 0 0}$ \\
\hline
\end{tabular}

Berdasarkan jenis kelamin, pasien Penyakit Ginjal Kronik yang menjalani hemodialisa dengan Virus hepatitis C memiliki distribusi pada laki-laki sebanyak 13 orang (52\%), sedangkan pada perempuan sebanyak 12 orang (48\%) (lihat Tabel 2).

Tabel 2. Distribusi Sampel Berdasarkan Jenis Kelamin

\begin{tabular}{lcc}
\hline Jenis Kelamin & Jumlah (Orang) & Persentase (\%) \\
\hline Laki-laki & 13 & 52 \\
Perempuan & 12 & 48 \\
\hline Jumlah & $\mathbf{2 5}$ & $\mathbf{1 0 0}$ \\
\hline
\end{tabular}


Berdasarkan jenis kelamin, pasien Penyakit Ginjal Kronik yang menjalani hemodialisa dengan Virus hepatitis B memiliki distribusi pada laki-laki sebanyak 10 orang $(71,42 \%)$, sedangkan pada perempuan sebanyak 4 orang (28,57\%) (lihat Tabel 3).

Tabel 3. Distribusi Sampel Berdasarkan Jenis Kelamin

\begin{tabular}{lcc}
\hline Jenis Kelamin & Jumlah (Orang) & Persentase (\%) \\
\hline Laki-laki & 10 & 71,42 \\
Perempuan & 4 & 28,57 \\
\hline Jumlah & $\mathbf{1 4}$ & $\mathbf{1 0 0}$ \\
\hline
\end{tabular}

Berdasarkan banyaknya tindakan hemodialisa, pasien Penyakit Ginjal Kronik sampai terdeteksi anti-HCV positif terdapat 20-100 kali ada 18 orang pasien PGK dan 5 orang pasien anti-HCV positif (27,78\%), kemudian antara 101-200 kali ada 31 orang pasien PGK dan 7 orang pasien anti-HCV positif (22,58\%), antara 201300 kali ada 20 orang pasien PGK dan 5 orang pasien anti-HCV positif (25\%), antara 301-400 kali ada 10 orang pasien PGK dan 4 orang pasien anti-HCV positif (40\%), antara 401-499 ada 4 orang pasien PGK dan 3 orang pasien anti-HCV positif (75\%), dan di atas 500 kali ada 4 orang pasien PGK dan 1 orang pasien anti-HCV positif (25\%).

Tabel 4. Distribusi Pasien PGK yang Menjalani Hemodialisa dengan Virus Hepatitis C Berdasarkan Banyaknya Tindakan Hemodialisa

\begin{tabular}{|c|c|c|c|}
\hline Frekuensi HD (kali) & Jumlah(Pasien PGK) & $\begin{array}{l}\text { Jumlah(Pasien Anti-HCV } \\
\text { positif) }\end{array}$ & Persentase (\%) \\
\hline $20-100$ & 18 & 5 & 27,78 \\
\hline $101-200$ & 31 & 7 & 22,58 \\
\hline
\end{tabular}




\begin{tabular}{lccc}
\hline $201-300$ & 20 & 5 & 25 \\
$301-400$ & 10 & 4 & 40 \\
$401-499$ & 4 & 3 & 25 \\
$>500$ & 4 & 1 & \\
\hline Total & $\mathbf{8 7}$ & $\mathbf{2 5}$ & \\
\hline
\end{tabular}

Berdasarkan banyaknya tindakan hemodialisa, pasien Penyakit Ginjal Kronik sampai terdeteksi HbsAg positif terdapat 20-100 kali ada 18 orang pasien PGK dan 2 orang pasien HbsAg positif (11,11\%), kemudian antara 101-200 kali ada 31 orang pasien PGK dan 6 orang pasien HbsAg positif (19,35\%), antara 201-300 kali ada 20 orang pasien PGK dan 5 orang pasien HbsAg positif (25\%), antara 301-400 kali ada 10 orang pasien PGK dan 1 orang pasien HbsAg positif (10\%), dan di atas 401 kali ada 8 pasien tetapi tidak ditemukan pasien dengan HbsAg positif.

Tabel 5. Distribusi Pasien PGK yang Menjalani Hemodialisa dengan HbsAg Positif Berdasarkan Banyaknya Tindakan Hemodialisa

\begin{tabular}{|c|c|c|c|c|}
\hline Frekuensi HD (kali) & Jumlah(Pasien PGK) & $\begin{array}{l}\text { Jumlah(Pasien } \\
\text { positif) }\end{array}$ & HbsAg & $\begin{array}{l}\text { Persentase } \\
\text { (\%) }\end{array}$ \\
\hline $20-100$ & 18 & 2 & & 11,11 \\
\hline $101-200$ & 31 & 6 & & 19,35 \\
\hline $201-300$ & 20 & 5 & & 25 \\
\hline $301-400$ & 10 & 1 & & 10 \\
\hline$>401$ & 8 & 0 & & 0 \\
\hline Total & 87 & 14 & & \\
\hline
\end{tabular}




\section{PEMBAHASAN}

Selama periode bulan September - November 2015 di SMF Ilmu Penyakit Dalam RSU Prof. DR. R. D. Kandou Manado khususnya di Unit Hemodialisis didapatkan 73 pasien yang menjalani hemodialisis dengan diagnosis Penyakit Ginjal Kronik, terdapa pasien dengan Virus hepatitis C berjumlah 25 orang (34,24\%). Angka ini lebih tinggi jika dibandingkan dengan penelitian sebelumnya yaitu $13,3 \%{ }^{7}$

Berdasarkan kelompok usia, pasien Penyakit Ginjal Kronik yang menjalani hemodialisis dengan Virus hepatitis C memiliki distribusi antara usia 18-29 tahun terdapat 1 orang (4\%), antara usia 30-39 tahun terdapat 2 orang (8\%), antara usia 40-49 tahun terdapat 8 orang (32\%), antara usia 50-59 tahun terdapat 8 orang (32\%), dan antara usia 60-69 tahun terdapat 6 orang (24\%). Hal ini berkorelasi dengan data yang ada bahwa jumlah pasien Penyakit Ginjal Kronik yang menjalani hemodialisis terbanyak adalah usia diatas 40 tahun sehingga peluang untuk mengidap Virus hepatitis C lebih besar pada usia tersebut. Seiring dengan bertambahnya usia maka daya tahan tubuh pun menurun sehingga lebih mudah terinfeksi penyakit.

Berdasarkan jenis kelamin, pasien Penyakit Ginjal Kronik yang menjalani hemodialisis dengan Virus hepatitis C memiliki distribusi pada laki-laki sebanyak 13 orang (52\%), sedangkan pada perempuan sebanyak 12 orang (48\%). Hal ini sesuai dengan penelitian sebelumnya yang menyatakan bahwa jenis kelamin lakilaki lebih banyak dari pada perempuan. ${ }^{8}$ Sedangkan pada pasien Penyakit Ginjal Kronik yang menjalani hemodialisa dengan Virus hepatitis B memiliki distribusi 
pada laki-laki sebanyak 10 orang (71,42\%), sedangkan pada perempuan sebanyak 4 orang $(28,57 \%)$.

Berdasarkan banyaknya tindakan hemodialisa, pasien Penyakit Ginjal Kronik sampai terdeteksi anti-HCV positif terdapat 20-100 kali ada 16 orang pasien PGK dan 5 orang pasien anti-HCV positif (31,25\%), kemudian antara 101200 kali ada 25 orang pasien PGK dan 7 orang pasien anti-HCV positif (28\%), antara 201-300 kali ada 15 orang pasien PGK dan 5 orang pasien anti-HCV positif (33,33\%), antara 301-400 kali ada 9 orang pasien PGK dan 4 orang pasien antiHCV positif (44,44\%), antara 401-499 ada 4 orang pasien PGK dan 3 orang pasien anti-HCV positif (75\%), dan diatas 500 kali ada 4 orang pasien PGK dan 1 orang pasien anti-HCV positif (25\%). Hal ini tidak sesuai dengan kepustakaan yang menyatakan bahwa semakin lama pasien menjalani hemodialisis semakin rentan untuk mengidap Hepatitis C. ${ }^{7}$ Pada pasien Penyakit Ginjal Kronik sampai terdeteksi HbsAg positif terdapat 20-100 kali ada 18 orang pasien PGK dan 2 orang pasien HbsAg positif (11,11\%), kemudian antara 101-200 kali ada 31 orang pasien PGK dan 6 orang pasien HbsAg positif (19,35\%), antara 201-300 kali ada 20 orang pasien PGK dan 5 orang pasien HbsAg positif (25\%), antara 301-400 kali ada 10 orang pasien PGK dan 1 orang pasien HbsAg positif (10\%), dan di atas 401 kali ada 8 pasien tetapi tidak ditemukan pasien dengan HbsAg positif.

\section{KESIMPULAN}

Jumlah kasus Penyakit Ginjal Kronik yang menjalani hemodialisis dengan Virus hepatitis C sbanyak 25 kasus (28,73\%) dan kasus dengan HbsAg positif sebanyak 14 kasus (16,09\%) dari 87 pasien. Pasien terbanyak berusia antara 40-49 tahun dan antara 50-59 tahun didominasi oleh laki-laki. Banyaknya tindakan 
hemodialisis sampai terdeteksi anti-HCV positif dan HbsAg positif terbanyak antara 101-200 kali.

\section{SARAN}

Bagi pihak Rumah Sakit, kiranya dapat lebih banyak melengkapi catatan medik pasien agar bisa diperoleh data yang lebih lengkap. Wajib melakukan pemeriksaan Virus hepatitis pada pasien baru dan rutin setiap 6 bulan. Melaksanakan kewaspadaan universal (Universal Precautions) yang ketat untuk pasien, petugas medis dan penggunaan alat medik/non-medik.

\section{DAFTAR PUSTAKA}

1. Suwitra K. Penyakit Ginjal Kronik. Dalam: Buku Ajar Ilmu Penyakit Dalam Jilid II, ed.5. Jakarta: InternaPublishing. 2009. h. 1035-40

2. Rahardjo P, Susalit E, Suhardjono. Hemodialisis. Dalam: Buku Ajar Ilmu Penyakit Dalam Jilid II, es.5. Jakarta: InternaPublishing. 2009. h. $1050-2$

3. Price S, Wilson L. Patofisiologi Vol 2. Jakarta: EGC. 2005. h. 972-6

4. Sanityoso A. Virus hepatitis Akut. Dalam: Buku Ajar Ilmu Penyakit Dalam Edisi IV Jilid I. Pusat Penerbitan IPD FK-UI; 2006. h.427-32

5. Deinstag J, Isselbacher $\mathbf{K}$. Acute Viral Hepatitis. Dalam: Harrison's Principles of Internal Medicine Sixteenth Edition. The McGraw-Hill Professional; 2005. h.1822-38

6. Rizetto M, Zoulim F. Viral Hepatitis. Dalam: Textbook of Hepatology Third Edition. Blackwell Publishing; 2007. h.821-2

7. Ujianto D. HCV PREVALANCE IN HEMODIALYSID UNIT \& ITS IMPLICATION TO CLINICALPRACTICE. [serial online] Diunduh 8 
November 2011. Tersedia dari: URL: HYPERLINK:

nefrologyners.wordpress.com

8. Jasuja S, Gupta A.K, Choudhry, et al. Prevalence and Associations of Hepatitis C Viremia in Hemodialysis Patients at a Tertiary Care Hospital. [serial online] diunduh 21 Januari 2011. Tersedia dari: http://www.indianjnephrol.org 